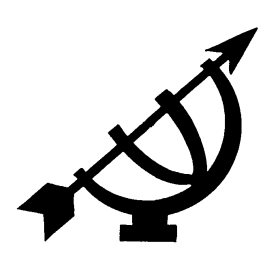

\title{
Eating disorders among adolescents in South African public schools - a biblical perspective
}

\author{
S. Schoeman \& H.M. Vogel \\ Department of Teacher Education \\ UNISA \\ PRETORIA \\ E-mail: schoes@unisa.ac.za \\ vogelhm@unisa.ac.za
}

\begin{abstract}
Eating disorders among adolescents in South African public schools - a biblical perspective
\end{abstract}

Society's obsession with thinness and body image is part of every school's hidden curriculum. The ideal to be skinny and thin resulted in an escalation in eating disorders among adolescents in South Africa. Some of the learners are only in the senior phase (Grades 7 to 9) of the general education and training band. It is therefore timely to review the problem of eating disorders, especially among adolescents in South African public schools. The purpose of this article is firstly to provide policy-makers, curriculum developers, educational administrators and educators with knowledge of the biblical view of health and to illustrate the pedagogical potential of such a view. Secondly the purpose is to assist Christian educators in teaching learners in public schools the necessary knowledge, skills, values and attitudes to counteract eating disorders by using, among other things, biblical truths.

\section{Opsomming}

Eetversteurings onder adolessente in openbare skole in Suid-Afrika 'n Bybelse perspektief

Die samelewing se beheptheid met maer-wees en liggaamsvorm, vorm deel van elke skool se verborge leerplan. Die strewe om maer en skraal te wees, het tot 'n toename in eetversteurings onder jongmense in Suid-Afrika gelei. Sommige van die leerders is maar slegs in die senior fase (Grade 7 tot 9) van die algemene-onderwys- 
en-opleidingsbaan. Dit is daarom tydig om die probleem van eetversteurings, veral onder adolessente in openbare skole in SuidAfrika te ondersoek. Eerstens is dit die doel van hierdie artikel om inligting aan beleidsmakers, leerplanontwikkelaars, onderwysadministrateurs en opvoeders aangaande die Bybelse siening van gesondheid oor te dra en die pedagogiese potensiaal van so 'n siening te illustreer. Tweedens is dit die doel om Christenopvoeders te ondersteun ten einde leerders met die nodige kennis, vaardighede, waardes en ingesteldhede toe te rus om eetversteurings die hoof te bied, deur onder andere van Bybelse waarhede gebruik te maak.

\section{Introduction}

According to scholars such as Ben-Tovim, Walker, Gilchrist, Freeman, Kalucy and Esterman (2001:357) one can think of food as the foundation of life, but for some people it could be the foundation of their misery. Eating disorders such as anorexia nervosa and bulimia nervosa are not new concepts - they were first described in the 17th century. According to Kaufman and Heiman (1965:83), the clinical presentation of these eating disorders appears essentially unchanged since the first comprehensive accounts were produced in the late 19th century. In the American Psychiatric Association's Diagnostic and Statistical Manual of Mental Disorders (1994:76) an eating disorder is defined as an "unhealthy eating pattern that can develop primarily among women, but is seen in men as well. The combination of cultural messages (where thin is the only acceptable body size), psychological issues, and low self esteem can set the stage for developing an eating disorder".

Eating disorders have also captured the South African public imagination. Images of severely emaciated young women suffering from anorexia nervosa appear often in glossy women's magazines and current affairs programmes, while public disclosure of bulimia nervosa has become commonplace (Carte Blanche, 2003; Sarie, $2002: 18,22)$. This publicity tends to obscure the continuing puzzle created by these enduring, hard-to-treat and sometimes fatal conditions (Nicolls \& Bryant-Waugh, 2003:67-68). It is therefore timely to review the problem of eating disorders, especially among adolescents in South African public schools. For the purposes of this article only the two major categories of eating disorders are applicable, namely anorexia nervosa and bulimia nervosa. According to the American Psychiatric Association's Diagnostic and Statistical Manual of Mental Disorders (1994:81, 83) anorexia nervosa is characterised by deliberate weight loss through avoiding fattening foods; whilst bulimia nervosa is characterised by repeated 
bouts of over-eating and intense preoccupation with controlling body weight. Sufferers of both these conditions may make themselves sick, take laxatives and exercise excessively in order to lose weight (the desire to lose weight is intense). These symptoms are not primarily about food. Food-related behaviour is symptomatic of underlying emotional and psychological difficulties. This is the way some people cope with difficult feelings and unresolved problems.

Hartmann (2003:1) describes society's obsession with thinness and body shape as body fascism, and asserts that it is part of every school's hidden curriculum. According to Hartmann (2003:4-5) body fascism may be described as "the severe intolerance in self and others of any weight or shape that does not resemble idealised bodies portrayed in media images ... often resulting in the rejection or bullying of those who do not conform to a specific body type". This means that many vulnerable young people will be so affected by the obsession with thinness that they proceed in developing an eating disorder (Marchuk, 1997:6-8). The need to be skinny has already caused a lot of eating disorders among young people in South Africa, starting as young as the senior phase (Grades 7, 8 and 9) of the general education and training band (Vogel, 2004:8). Scholars such as Delaney, Erskine, Langridge, Smith, Van Niekerk, Winters and Wright (1995:992-993), Norris (1996:39-45), Schutte (2004:9) and Vogel (2004:9) claim that in every school in South Africa there is a significant percentage of learners with eating disorders. A close reading of research findings in 1994 reveals that $2,6 \%$ white learners and 1,7\% non-white learners experienced problems with eating disorders. In comparison to the 1994 figures, a decade later, in 2004, the situation worsened and 2,8\% white learners and 2,0\% non-white learners suffered from an eating disorder.

According to scholars such as Andersen and DiDomenco (1992: 283-284) and Waller and Shaw (1994:44-45) it is difficult to account for the increase in eating disorders in Western, Asian and African societies. However, some suggestions have been offered, such as the mass media, family, friends and school. As the focus in this article is on the role of the school and the Bible in the prevention of eating disorders among adolescents in South Africa, only the school's contribution to the problem will be discussed. According to Hartmann (2003:3) schools play a crucial role in creating and fostering a culture of intolerance in learners, which in turn affects society. Educators especially are fundamental in developing intolerance in many areas, which include body fascism and eating disorders (Sours, 1980:121). As sports and physical activities 
trainers, educators are particularly well placed to contribute to problems faced by adolescents in this regard, such as the teasing of overweight learners, the perception that overweight learners will not be able to achieve high levels of success, etcetera. Learners fear being picked last in a team due to perceived physical unsuitability. Hence, they are self-conscious about body shape and develop selfesteem that is dependent on body size (Connell, Turner \& Mason, 1985:316-318).

After the first democratic elections in 1994 an educational approach known as Outcomes-based Education was introduced (National Department of Education, 2001:1, 2). According to the National Department of Education (2001:14) Outcomes-based Education may be defined as "... a process and achievement-oriented, activitybased and learner-centred educational approach". The way in which the outcomes were described, inevitably led to the implementation of a humanistic and horizontal approach to education (National Department of Education, 2001:27, 31). The separation of church and school is advocated and government tends to view religion as a private matter, without a clearly defined social role in schools as public institutions (Republic of South Africa, 1996:6). Scholars such as Coetzee (1984:36) and Stoker (1941:24) demonstrate that the Bible as the Word of God provides direction for life as a whole. Therefore, teaching and education can never be neutral. McLaughlin (2004:109-110) confirms that “... education cannot be value-free. Every action ... of a teacher is value-laden, and so is every aspect of a school"; whilst Halstead \& Taylor (1996:239-255) proclaim that "Education is inherently saturated with value ... educators cannot avoid fundamental questions such as: which values should education embody and transmit, why and how". Consequently, biblical truths can offer valuable perspectives about caring for those learners suffering from eating disorders. In terms of the Constitution of the Republic of South Africa, 108 of 1996 (Republic of South Africa, 1996:6), educators and learners enjoy the fundamental right of freedom of opinion and expression in schools as public institutions. Christian educators could therefore contribute to solving the problem of eating disorders among adolescents in South African public schools by using biblical truths in their teaching activities, which learners can either accept or reject. The problem that underlies this article therefore centres around the following question: How should the problem of eating disorders among adolescents in South African public schools be approached from a biblical perspective? 
The main aim of this article is to provide policy-makers, curriculum developers, educational administrators and educators with knowledge of the biblical view of health and to illustrate the pedagogical potential of a Scriptural perspective and Scriptural truths. This article also attempts to assist Christian educators in teaching learners in public schools the necessary knowledge, skills, values and attitudes to counteract eating disorders by using among other things biblical truths. This article comments on the following: the biblical view of health and the role of the school and the Bible in the prevention of eating disorders among adolescents in South African public schools. Special reference is made to the role of the educator in the Life Orientation classroom, as a trainer of sports and physical activities, as an adviser in the school and in the community and as pastoral tutor.

\section{Perspective of the study}

The revelationary nature of the Scriptures should be taken into account in all educational research. God as Creator of all things, was never created Himself. He is dependent on nothing, but creation is dependent on Him for their existence, and God reveals Himself to man through his creation and through his Word. Creation is the product of the hand of God and is called into existence through his authoritative Word. Creation itself consists of a variety of phenomena, and God rules over and dominates creation through the laws He has provided for this purpose.

Knowledge of the science of education is formed in the light of the Scriptures, and Scripture is also a source of educational research. The Bible contains truths and norms of a decisive nature for educational research, providing direction and guidance for educational researchers (Stoker, 1941:41). Seen from the true perspective (the actual purpose) of Scripture and Scriptural authority, the Bible presents itself to educational researchers as the authoritative Word of God. Educational researchers can never claim that education is a discipline on which God's Word has no jurisdiction. In fact, Christian educational researchers should profess that God has revealed Himself authoritativelely in his Word in such a way that He should be approached as God of the whole creation. His will was given to mankind as a rule and precept for their everyday life, in all its facets, including their educational research task (Coetzee, 1984:23). Thus the perspective of this article rests on the Bible as the Word of God. 


\section{Biblical view of health}

To understand the biblical view of health, one should, according to Walker (2003:1-16), commence with the book of Genesis. In the opening pages of Genesis the first man and woman who were created by God, were perfect in health, and perfect in their relationship to their surroundings and to God. There was no sickness and no death. The vegetation of the garden of Eden was their sustenance. However, there was one tree in the garden from which the man and woman were forbidden to eat. The result of eating the fruit from this tree (death) was a punishment from God for disobedience. The "wisdom" that the man and woman gained by eating the forbidden fruit was the experience of sin. The definition of sin is simply "disobedience to God". The Bible also calls sin "lawlessness" (1 John 3:4). Adam and Eve only had one law to obey (a law about what they should eat) and they disobeyed it.

Adam and Eve did not drop dead the moment they ate the forbidden fruit. What actually happened, was that the process of death began that day and their bodies began to age and decay - finally resulting in physical death. The perfect harmony between man and beast, man and nature, and man and God was disrupted. God drove the man and woman out of the garden, away from His presence. Sin and death became the inherited curse of the human race, and were passed on to Adam and Eve's descendants up until the present time (Rom. 5:12). Fortunately, God did not leave the human race in this helpless condition. He sent forth His son to die for mankind's sins, so that man could have a cure for death. Jesus Christ came into the world and lived a perfect sinless life (1 Pet. 2:22). Not having to be punished for His own sins, because He had none, Jesus Christ nevertheless willingly took upon Himself the curse of death and became a sacrifice for the sins of the human race (2 Cor. 5:21). However, since Jesus Christ was the perfect Son of God, death had no power over $\mathrm{Him}$, and $\mathrm{He}$ was raised from the dead on the third day (1 Cor. 15:3-4). Because of Jesus Christ's sacrificial death on the cross for all man's sins, the cure for death is now available to all. God offers this cure to all as a free gift (Rom. 6:23). The receiving of something from God that mankind do not deserve, is called grace. The only condition on man's part to receive this gift, is faith. Man needs to believe that God is so good and gracious, that He is giving him/her eternal life through Jesus Christ's sacrifice (John 3:16). It is essential that man understands the concept that God is giving him/her eternal life and that there is nothing he/she can do to earn it. God deserves all the credit (Eph. 2:8-9). 
It is from this view that a discussion on the biblical view of health should begin. One should understand that sickness exists because of $\sin$ and that the final result of $\sin$ is death. The promise of a new, perfect body awaits those who have received forgiveness of sins and salvation through faith in Jesus Christ (1 Cor. 15:51-57). When a person receives God's free gift of eternal life, he/she becomes a new person (1 Cor. 15:17). Jesus referred to this as being born again (John 3:5-6). This new birth and new creation refer to man's spirit. God's Holy Spirit actually comes to reside within man as a sign of God's ownership over him/her (Eph. 1:13; Van der Walt, 1999:1-4).

Unfortunately, man's body is still marred by the curse of sin - until he/she sheds it for an immortal body in the resurrection (1 Cor. 15:51-57). While man's spirit is alive because of his/her union with Christ, his/her body is still "dead" (in the process of getting old and decaying), because sin is still present in his/her life. However, man is not without hope for good health in this life. He/she has the promise that if God's Spirit dwells within him/her, He will give life (and health) even to the mortal bodies. In order to experience life and health in his/her present mortal body, which is growing old and is decaying, man must live according to the Holy Spirit - by walking in the path of righteousness and good living, rather than living according to the flesh, and walking in the path of sin and wrong living (Rom. 8:9-13; Shilhavy, 2002:4-7). Galatians 5:16-22 defines the "deeds of the body" as follows:

But I say, walk by the Spirit, and you will not carry out the desire of the flesh. For the flesh sets its desire against the Spirit, and the Spirit against the flesh; for these are in opposition to one another, so that you may not do the things that you please. But if you are led by the Spirit, you are not under the Law. Now the deeds of the flesh are evident, which are: immorality, impurity, sensuality, idolatry, sorcery, enmities, strife, jealousy, outbursts of anger, disputes, dissensions, factions, envying, drunkenness, carousing, and things like these, of which I forewarn you just as I have forewarned you that those who practice such things shall not inherit the kingdom of God. But the fruit of the Spirit is love, joy, peace, patience, kindness, goodness, faithfulness, gentleness, self-control; against such things there is no law. 


\section{The role of the school and the Bible in the prevention of eating disorders among adolescents}

\subsection{Introductory remarks}

According to the World Health Organisation's definition of health promotion, public schools are an important arena for health promotion. Schools are everywhere, and everyone is obliged to attend school. Hence, school-based programmes offer the opportunity to reach the entire learner population, especially the adolescents with eating disorders (WHO, 1993:38). School employees play an important role in the transmission of culture, the shaping of peer interactions, and the development of knowledge about the body and the self. Thus they can make a significant impact on the prevention of eating disorders (Levine, 1983:45-47).

According to Gottesfeld (1979:19-21) the mental health programme traditionally recognises three types of prevention, namely, primary-, secondary-, and tertiary prevention.

- Primary prevention eliminates or reduces socio-cultural factors that increase the risk of eating disorders, such as the stigma attached to being overweight, or misconceptions about the body's regulation of weight. Thus, primary prevention involves the monumental task of preventing eating disorders by changing the behaviour of those groups (learners, educators, the entire school staff and parents) who influence body image, self-esteem, eating habits, coping skills, etcetera.

- Secondary prevention is the early identification, accurate referral, and prompt treatment of individuals in the initial phases of anorexia nervosa or bulimia nervosa. Its goal is to prevent acute problems from becoming severe and chronic eating disorders.

- Tertiary prevention corresponds to the full-scale treatment of severe eating disorders.

Effective treatment will prevent the individual from having subsequent episodes of the disorder. The guiding principle is that all school employees, especially educators, can contribute significantly to primary and secondary prevention. Tertiary prevention or treatment will therefore not be discussed in this article.

Every Christian has to wrestle with numerous issues in his/her personal life, and so must the Christian educator. Questions such as how should I deal with certain issues, or what should I think of this, or what attitude should I adopt toward my learners, are typical 
questions in the normal course of school life. To answer these questions, the educator requires norms - norms that should be the guidelines for his/her convictions and behaviour. Although there is a wide range of norms, the law of love is the cornerstone of the Christian life. Jesus Christ succinctly summarised the love commandment as love for God and for one's neighbour. The Christian educator can and should turn to the Scriptures to find the normative basis for his/her behaviour inside and outside the classroom.

\subsection{The educator and primary prevention}

\subsubsection{The educator in the classroom}

In this section two aspects of the Life Orientation educator's role in the classroom are described, namely, general principles for discussing eating disorders with learners in the Life Orientation classroom, and a learning unit on eating disorders that educators can use as a guideline to design their own learning units on eating disorders to teach learners in the senior phase (Grades 7 to 9) and in the FET (Grades 10 to 12) Life Orientation classroom.

\subsubsection{General principles for discussing eating disorders in the Life Orientation classroom}

The teaching of educators with regard to eating disorders will be fruitfull if they can foster an attitude and belief in learners to say: "Regardless of my weight and shape, I like myself. I do not need to drive myself to be thinner or more accomplished. It would not matter if I gained weight or lost weight, I would still be me, a worthwhile person." (Bayer \& Baker, 1984:12). According to Levine (1983:266267) opportunities to initiate the above attitudes and behaviours often arise spontaneously from classroom discussions and activities.

Educators may keep the following principles in mind as set out by scholars such as Levine (1983), Peters (1994), Pratt (1983) and Wooley and Wooley (1985). Life Orientation educators play an important role in transmitting attitudes, shaping learners' beliefs about themselves, and enable learners to make informed choices about eating and weight. It is therefore important that Life Orientation educators constantly examine their personal attitudes towards eating, weight and self-concept. This exercise will probably lead to a consideration of their own body image, self-esteem, eating patterns, exercise habits, and their attitudes about underweight, normal weight and overweight people (Wooley \& Wooley, 1985: 
391). This will make them more sensitive listeners, and will ensure that their lifestyle and non-verbal communications do not contradict their statements about the importance of personality over external appearance. Life Orientation educators should strive to maintain a classroom environment that enhances the diversity of the human nature. They should design teaching and learning activities that make all learners feel comfortable and valued, and ensure that what learners see and how learners are treated clearly communicate that personality and individuality are more important than external appearances (Levine, 1983:61-62).

According to Pratt (1983:165-167) eating, weight, and self-concept are emotionally charged issues for adolescents - particularly girls and overweight boys. Life Orientation educators can demonstrate sensitivity to these authentic concerns by pointing out to learners the difficulties involved in discussing the subject; allowing learners ample time to comment or not comment as they see fit; avoid forcing any learners to participate in the class discussion; introduce the topic in a non-threatening way; take steps to ensure that the discussion remains positive; ensure that the information presented is accurate; and that no person or "type" of person (such as obese models) is ridiculed, blamed or otherwise singled out.

Given the high prevalence of eating disorders and unhealthy eating habits among adolescents, it is virtually certain that there will be at least one adolescent in the Life Orientation classroom with an eating disorder. Life Orientation educators should immediately make it clear that their discussion of eating disorders is didactic and not therapeutic, and establish a zero tolerance stance on teasing, taunting and negative talk about learners' bodies in the classroom and in the school. Derogatory behaviour should be treated the same way as racial or sexual harassment (Peters, 1994:3-4).

\subsubsection{An example of a Life Orientation learning unit on eating disorders}

The following learning unit on eating disorders is provided as guide for Christian educators who wish to design a Life Orientation learning unit on eating disorders as knowledge focus area that uses biblical truths. For the topic "Eating disorders: when food becomes an enemy"; the learning outcomes for the learning unit may be the following:

- to discuss the issue of body image and how it can affect a person's thoughts, feelings and behaviour; 
- to outline what the Bible teaches about body image;

- to define the concepts body image and eating disorders;

- to identify and describe the symptoms of the most prevalent eating disorders and indicate how they damage the body;

- to describe the possible causes of eating disorders;

- to identify where people with eating disorders can get help; and

- to name and describe the five steps that the Bible teaches Christians to overcome illnesses, such as eating disorders.

To ascertain the learners' existing knowledge, learners are individually assigned to find an article about someone with an eating disorder, using popular magazines and newspapers. The learners should summarise the article and be able to discuss it with the class. Then the facilitator writes the following question on a flash card: What would you like to change about your body image? Why? Learners are instructed to write on a piece of paper a response to the question. The facilitator emphasises that the learners will not have to turn in their answers or share them with anyone.

The facilitator then writes the following questions on the chalkboard and initiate a discussion on the questions: Why are physical traits so important to people? Is physical appearance more important than someone's personality? What does the saying "Beauty is only skin deep" mean? What does 1 Peter 3:3, 4 say about self-worth? The facilitator instructs the learners to form three groups and each group reads the following passages in the Bible: 1 Peter 3:3, 4; 1 Samuel 16:7; Ephesians 4:22-24; Ephesians 5:29; Luke 12:6, 7. Then they list the ways in which the Scripture readings demonstrate how to develop positive self-worth and healthy self-respect. The reporter from each group can report his/her group's findings to the class. Learners are then instructed to look around the room at their peers and list at least three similarities and three differences they share. The facilitator explains that the differences in people make them unique. The learners should then individually list at least three positive characteristics that make them unique.

The facilitator divides the learners into small groups and instruct them to collect information on the following headings from the school's media centre: the most prevalent eating disorders and their symptoms; the causes of eating disorders; the medical complications that often result from eating disorders, and how these diseases can be life-threatening; the prevention and early detection of eating disorders; the different methods of treating eating 
disorders. Based on the information learned and discussed in the class each group must prepare a tri-fold pamphlet for senior phase (Grades 7 to 9) learners to make them aware of eating disorders. After the learners have completed their pamphlets, the facilitator can let the class vote on the most effective pamphlet and make copies of that pamphlet for distribution in the school (Soderquist, 2002:4-5).

The facilitator then distributes copies of the following hand-out which contains an extract dealing with the biblical view of health (see par. 3. Biblical view of health):

While man's spirit is alive because of his/her union with Christ, his/her body is still 'dead' (in the process of getting old and decaying) because sin is still present in his/her life. However, man is not without hope for good health in this life. He/she has the promise that if God's Spirit dwells within him/her, He will give life (and health) even to the mortal bodies. In order to experience life and health in his/her present mortal body, which is growing old and is decaying, man must live according to the Holy Spirit - by walking in the path of righteousness and good living, rather than living according to the flesh, and walking the path of sin and wrong living.

The learners read the above extract and complete the following questions in their workbooks: Why is man's spirit alive but his/her body is still in the process of decaying? Why can man hope for good health in this life? What should man do to experience health in his/her present mortal body? What should man avoid in order to experience life and health in his/her present mortal body? What does this biblical view of health teach Christians about the prevention of and intervention in eating disorders? Finally, the facilitator can assess (by means of product assessment) the learners' understanding of the biblical view of health.

The learning unit can be concluded with the following homework assignment: Firstly, learners are instructed to imagine that they have noticed signs of a possible eating disorder in a good friend. They should write a letter to their friend in which they explain to him/her the signs that he/she is showing and how the disease will hurt him/her. In the conclusion of the letter he/she should let his/her friend know what the friend can do to receive help with the illness. Secondly, learners are instructed to design a five step biblical prevention programme, using the following five passages from the Bible in chronological order: Philippians 3:19 (Repent); James 4:7 (Surrender to God); 1 John 5:14-15 (God's plan); Romans 8:1-4 (Thank God); Matthew 6:17-18 (Fasting). After they have completed 
the above prevention programme, they should recommend the programme to their friend in an e-mail message (Dairy Council of California, 2003:1-3; Levine, 2003:18-24; Ministry of Education, 2003:1-9).

\subsubsection{The educator as sports and physical activities trainer}

If a crucial component of the prevention of eating disorders is removing the emphasis from slenderness and promoting self-esteem via self-acceptance, then it is reasonable to believe that the educator as trainer of sports and physical activities, can also help to prevent eating disorders among adolescents in South African public schools (Garner \& Garfinkel, 1985:3). Learners should be allowed to participate in sports and physical activities, regardless of their body weight or shape. Being "in shape" to participate, should not be construed a need to mortify the flesh. Learners should not be driven to excel in a manner that encourages them to treat their bodies as enemies that should be conquered, and weight loss should not be advocated as a solution to the problem of improvement (Garner \& Garfinkel, 1985:4-6).

Given the importance of educators as trainers of sports and physical activities in tackling body fascism, there are various things which educators can do to address body fascism as part of the hidden curriculum. According to Allensworth and Kolbe (1987:409-410) educators could, for example, survey learners' views about their sports and physical activities in such a manner that the learners' opinions in this regard can be heard. The following topics may be included in a survey questionnaire: learners' likes or dislikes about sports and physical activities; how learners might want their sports and physical activities to be different; learners' attitudes to shape or size difference (in relation to their own shape or size), and how this affects them in relation to sports and physical activities; how learners can enjoy sports and physical activities more if this is a problem; how learners may support peers who are victims of body fascism; how learners may plan sports and physical activities to address body fascism and increase their enjoyment of sports and physical activities; what would help them or their peers to feel more comfortable and included in sports and physical activities. Educators may use the learners' responses to the survey to redress and transform their sports and physical activities in order to create opportunities for fitness and enjoyment for all learners. It is essential that learners of all body shapes and sizes feel included and valued for their contributions, even if they are not able to achieve high levels of success. 


\subsection{The educator and secondary prevention}

\subsubsection{The educator as adviser in school: Identifying and referring at-risk learners}

At what point should an educator become concerned that a learner is at risk of developing an eating disorder? When does typical adolescent concern with body image, food and weight crosses the line and begins to reflect an eating disorder? According to BryantWaugh (1992:52) the rule of thumb is to treat any warning signs or symptoms seriously. What should an educator then do with the information about a potential eating disorder? Concerned educators are advised to keep concise notes of the incidents that have led them to suspect that a learner has a problem. The notes should focus on specific observed behaviours, without attempting to reach any definitive conclusion. Educators should not attempt to "diagnose", but their careful observations may assist clinicians in the diagnostic process (Government of British Columbia, 2003:1). A learner with a suspected eating disorder should not be confronted. However, a situation may arise when it becomes necessary to talk directly to the learner about the problem. The learner may either approach a trusted educator to express concern regarding his/her own health or the health of a friend. Specific learning units that look at the issue of eating disorders can also spark such queries (Government of British Columbia, 2003:13).

Since eating disorders generally emerge during the secondary school years, it is often difficult for a single educator to identify potential danger signs. If an educator has a concern, he/she may want to compare notes with other educators. It is important that educators also share any concerns of this nature with the school counsellor and, perhaps, a school administrator. In many cases, the school counsellor may already be aware of the problem and will be able to offer the educator support and advice. The school counsellor is in the best position to deal with the learner and his/her family, and should be able to direct them to the most appropriate medical resources (Ministry of Education, 2003:56-57). The effective treatment of eating disorders requires a professional therapist with special training and considerable skill. Such treatment is not the province of educators or school counsellors. Educators should therefore be informed about the referral process in the school system. The school administrator, school counsellor or school psychologist could be asked for specific information about steps involved in verifying the presence of an eating disorder and 
arranging for proper services (O'Neill, 1982:101-104; Pratt, 1983:7274).

\subsubsection{The educator as an adviser in the community (as public educator)}

Life Orientation and sports and physical activities educators who are very committed to the prevention of eating disorders, may wish to become involved in educating the public about eating disorders, and the role of the school system in prevention. According to Levine (1983:614-615) and Tootell $(2000: 14,15)$ two of the foremost ways in which educators can contribute to public education are public speaking and use of the media.

Life Orientation and sports and physical activities educators can combine their communication skills, knowledge of eating disorders, and position of respect in the community to present effective presentations on the topic of eating disorders to various community groups, civic groups, child protection bodies, mental health associations, adult education classes, fraternal groups, etcetera. One need not be an expert clinician to provide people with good basic information about the nature of eating disorders, warning signs, resources for treatment, socio-cultural factors, and the role of public education. In fact, most of these groups are constantly searching for local speakers with topics of current interest.

Particularly in smaller towns, where the number of staff for the writing of stories is low and the interest in local accomplishments is high, the newspaper may be delighted to publish an article on eating disorders by an educator. Educators of languages, Life Sciences, Home Economics or Life Orientation could ask learners in the class to write such an article and then submit it to the paper under joint authorship. Life Orientation and sports and physical activities educators who do not have the inclination or time to write about eating disorders may choose to obtain pamphlets from an eating disorders association. These can be distributed to any number of organisations that are willing to display them, for example public libraries, churches, doctors' and dentists' waiting rooms, and supermarket bulletin boards. If the association has only a limited number of free pamphlets, the committed educators could consult the local or national mental health association, or a nearby hospital, about the possibility of securing funds for the purchase of sufficient numbers of pamphlets. Most radio stations have at least one community affairs programme. There is no reason why a Life Orientation and sports and physical activities educator would not be 
welcome to discuss topics such as adolescent development, eating disorders and the school system on this kind of programmes.

\subsection{The educator as pastoral tutor}

Eating disorders are one of the problems that the Christian educator as pastoral tutor is involved with in school. Eating disorders indicate a problem at the mental health level. According to Aist (1990:711) the concept of mental health can be defined as follows:

Mental health is a condition of well-being in relation to self and others characterized by such qualities as (a) positive selfacceptance, (b) accurate perception of others and the world, (c) stability and appropriateness in mood, (d) balance and purposiveness in behavior, (e) dependable sense of identity and values, ( $f$ ) adaptability to one's environment, $(g)$ ability to engage in productive work and fulfilling love, and (h) commitment to a source of devotion beyond oneself. As such mental health is an active process - not merely the absence of illness.

Mental health is therefore an indication of general well-being. The compass of the gospel of Jesus Christ also includes aspects of human well-being. The Christian educator's concern for learners' mental health is a specific manifestation of his/her role as pastoral tutor in school (Anderson, 1989:123). The school is a life-creating context. Learners' lives are touched and influenced by teachinglearning activities, discussions and interpersonal contact. According to De Jongh van Arkel (1985:18) the content and quality of Christian belief functions at the level of primary mental health and creates a situation that equips adolescents to work through crises and misfortune. The Christian theme of life and liberation as God's gift to humankind could therefore be impressed upon the learners by the educator as pastoral tutor by using among others biblical-oriented teaching-learning activities. By doing so the educator can create a context of life and hope for the adolescent, promoting mental health and having an inhibitory effect on destructive behaviour. If the gospel of Jesus Christ is internalised in an adolescent's life, it creates a situation that will not promote eating disorders. Some guidelines in this regard follows.

\subsubsection{Personal faith and mental health}

The relation between the adolescent's personal faith (or religion) and mental health should come under the spotlight in classroom teaching-learning activities. However, the Christian educator should seriously take into account the complex nature of the relationship 
between these two aspects. It is not so easy to demonstrate a linear causal connection between Christian convictions and mental health. There is always the possibility that the relationship can also be understood in reverse: that increased participation in Christian religious activities at school and intensified religious experience can reflect an increase in well-being; but at the same time it is not necessarily Christian "religiosity" as such that guarantees mental health (Oates, 1970:16). Although Christian convictions, therefore, do not guarantee mental health, the gospel of Jesus Christ is in essence life-giving (De Jongh van Arkel, 1990:1). Research by Ferraro and Albrecht-Jensen (1991:194) has shown that biblicaloriented teaching-learning activities have a positive impact on adolescents' mental health or psychological well-being.

\subsubsection{Social support and social integration}

According to Bufford and Buckler (1987:26), two of the factors that are associated with positive mental health are meaning and purpose in life, and involvement in a social support system in the school. The research that has been done by Idler (1987:228-229) is of importance for the Christian educator's involvement with adolescents with eating disorders. She found indications that four mechanisms of biblical-oriented teaching-learning activities in the school have a positive effect on health:

- Healthy behaviour - biblical-oriented teaching-learning activities reduce behaviour that is destructive to health.

- Social cohesion - biblical-oriented teaching-learning activities activate a social network that helps to deal with problems and to support learners.

- Cognitive coherence - biblical-oriented teaching-learning activities activate a special meaning system that makes sense of life.

- Interactive theodicy - biblical-oriented teaching-learning activities modify perceptions of distress that are associated with physical suffering and in this way often give hope to the individual.

The research of Ellison, Gay and Glass (1989:117) also moves in the same direction when they conclude that biblical-oriented teaching-learning activities in schools may influence individual satisfaction with life by reducing the negative impact of stressful living conditions and occurrences. These activities may equip adolescents with personal resources that are functional in dealing with trauma, reinforce shared values, and provide the necessary 
explanation or interpretation of life events. It would appear that the support that exists in schools has a positive effect on the mental health of adolescents, since it gives them access to emotional, cognitive and material support in times of need (Ferraro \& AlbrechtJensen, 1991:200).

Regarding the support aspect of biblical-oriented teaching-learning activities, it is also important to take into account the qualitative difference between a social network and a social support system. While a social network is defined in terms of a focus person and association with people who are important to you, a social support system consists of people who can serve as buffers against psychosocial stress and/or help you to adjust to stressful situations. The social network is not necessarily a help, because it might even include people who aggravate the adolescent's stress (Walfish \& Weinberg, 1979:124). A social support system implements the exhortation of Galatians 6 and Romans 15 that Christians should help bear each other's burdens and weaknesses. This is, therefore, theological justification for a social support system. Furthermore, it can also be psychologically justified: anyone who is going through situations that either cannot be changed or change very slowly, such as eating disorders and which, therefore, can give rise to feelings of helplessness, needs support. Support offers encouragement, comfort and reassurance to adolescents in need. Where functional support is offered at a school, the adolescents who are exposed to it will not be overwhelmed by feelings of hopelessness when they have to deal with their various problems (Pearson, 1982:83).

According to Petersen and Roy (1985:59), the finding that biblicaloriented teaching-learning activities in school contribute to a feeling of subjective well-being, relates to the increased social integration that it usually brings about. They find that the social support function of the activities contribute more toward an adolescent's ability to deal with set-backs than religious belief and orientation alone. The significance of the social side of religion is emphasised here. The regular basis of activities feeds friendships and social connections. At the same time it brings adolescents in contact with others who might have had the same experiences. It would therefore appear that the existence of biblical-oriented teaching-learning activities in schools does not necessarily imply that life has meaning and purpose for adolescents. A caring ecology is not adequate to sustain adolescents in all situations that make them feel that life no longer has meaning. The important element lies in the supportive aspect of the biblical-oriented teaching-learning activities in schools. 


\subsubsection{Hope, hopelessness and helplessness}

While hope is a central theme in the Bible as the Word of God, the feeling of hopelessness is a dominant phenomenon for adolescents with eating disorders (Olivier et al., 1991:282). Hopelessness is also associated with helplessness: the conviction that one has no further capacity to resolve problems. Feelings of hopelessness, helplessness and depression (which are prominent in adolescents with eating disorders) feed on each other. There is always the possibility that hope in a hopeless situation does not teach adolescents to work through and resolve problems, but in fact to avoid them (Kovaks, Beck \& Eissman, 1975:102). Biblical-oriented teaching-learning activities must teach the message of the coming of Jesus Christ and his Spirit to adolescents in such a way that it has existential value for them who are so caught up in their apparently unresolvable problems, that they have lost all hope. Within a situation dominated by the apocalypse, there should also be room for an existential eschatology. Eschatology only exists as extrapolation of experiences that Christians acquire with God in their own world and history, and the knowledge of the fidelity of God is grounded in their knowledge of God's involvement in the past and the present. Belief in a real relationship with God and his normative presence forms the basis of all salvation. This truth confronts the Christian educator as pastoral tutor with the difficult task of making the God who works in the present and for the present a reality for adolescents too (Berkhof, 1968:160; Berkhof, 1973:16; Vriezen, 1966:467).

\section{Conclusion}

In order to prevent and reduce the incidence of eating disorders among adolescents in South African public schools, health care professionals for many years have been visiting schools to target learners with programmes in order to prevent eating disorders. The most usual approach has been that the school arrange a day where the focus is eating disorders. In other words, the learners listen to various topics related to eating disorders; perhaps watch a video of the development of eating disorders, or a patient presents her/his life story. However, the crucial question is whether this approach actually reduces the incidence of eating disorders or the frequency of the symptoms of eating disorders?

This article argues that the above method is not the best way to target the problem of eating disorders in South African public schools. Behavioural change usually comes from sources other than factual knowledge. Primary and secondary prevention is a more 
fruitful approach. The primary prevention of eating disorders requires the elimination of factors that place adolescents at risk of developing eating disorders. Such problems reflect socio-cultural influences to some extent, and the school is a very important part of social experience during the adolescent years. Caring, well-informed and sensitive educators can make a difference. Educators who work within a supportive school system are in an excellent position to help combat ignorance, promote healthy development, and transform socio-cultural influences from a risk factor into a preventive force. The secondary prevention of eating disorders requires an awareness by school employees (especially educators) and learners of the warning signs of an eating disorder, the resources for professional therapy, and the basic skills involved in helping anorexic and bulimic learners receive effective treatment. With eating disorders in particular, a short duration of the disorder is a very strong indicator of successful treatment. Given the amount of time adolescents spend away from home, peers and educators are often in a better position to observe, acknowledge and act upon the early signs of anorexia nervosa and bulimia nervosa than the family.

Christian educators should use biblical-oriented teaching-learning activities to introduce their learners to a relationship with God. There is nothing more important to prevention or intervention than this relationship. A learner who wishes to put an eating disorder behind him/her has to meet Jesus Christ the Saviour, and make Him Lord of his/her life. Anyone who sincerely seeks God through faith in Jesus Christ and spends time in His presence and get to know Him, will see the results - the eating disorder cannot continue. Christians who are serious about God are being conformed, one day at a time, into the likeness of Jesus Christ. If Christians cast the cares of their eating disorder onto Him, the bad thoughts and behaviour patterns will be annihilated (Yates, 2000:18).

\section{List of references}

AIST, C.S. 1990. Mental health and illness. Nashville: Abingdon.

ALLENSWORTH, D.D. \& KOLBE, L.J. 1987. The comprehensive school health program: Exploring an expanded concept. Journal of School Health, 57(10):409-412.

AMERICAN PSYCHIATRIC ASSOCIATION. 1994. Diagnostic and statistical manual of mental disorders. Washington: APA.

ANDERSEN, A.E. \& DIDOMENCO, L. 1992. Diet v shape: Content of popular male and female magazines: A close-response relationship to the effect of eating disorders. International Journal of Eating Disorders, 11:283-287.

ANDERSON, H. 1989. The "congregation" in school: Health center or healing community. Word \& World, 11:123, 131. 
BAYER, A.E. \& BAKER, D.H. 1984. Not just a skinny kid: The anorexic or bulimic teenager. New York: National Mental Health Association.

BEN-TOVIM, D., WALKER, K., GILCHRIST, P., FREEMAN, R., KALUCY, R.S. \& ESTERMAN, A. 2001. Outcome in patients with eating disorders: A 5 year study. Lancet, 35(7):1254-1257.

BERKHOF, H. 1968. Gegronde verwagting; schets van een Christelijke toekomsleer. Nijkerk: Callenbach.

BERKHOF, H. 1973. Christelijk geloof: een inleiding tot de geloofsleer. Nijkerk: Callenbach.

BRYANT-WAUGH, R. 1992. Do doctors recognise eating disorders in children. Sussex: Psychology Press.

BUFFORD, R.K. \& BUCKLER, T.B. 1987. The church and community mental health: Unrealized potential. Journal of Psychology and Theology, 10:355362.

CARTE BLANCHE. 20 July 2003: Eating disorders. Johannesburg: M-NET.

COETZEE, J.C. 1984. Die Skrif en die wetenskap: Hermeneutiese reëls. Potchefstroom: $\mathrm{PU}$ vir $\mathrm{CHO}$.

CONNELL, D.S., TURNER, R.R. \& MASON, E.F. 1985. Summary of findings of school Health Education: Health promotion - effectiveness, implementation and costs. Journal of School Health, 55(8):316-321.

DAIRY COUNCIL OF CALIFORNIA. 2003. Shaping a healthy body image lesson plan. http://www.pbs.org/in them./educations/lessons/selfimage/ [3 Dec. 2003].

DE JONGH VAN ARKEL, J.T. 1985. Gesinsmoord: 'n Pastoraal-teologiese perspektief. Suid-Afrikaanse Tydskrif vir Strafreg en Kriminologie, 9:140148.

DE JONGH VAN ARKEL, J.T. 1990. Making religion work in the family. Referaat gelewer by die konferensie van die Suid-Afrikaanse Nasionale Raad vir Geestesgesondheid. Johannesburg.

DELANEY, N.E., ERSKINE, P.J., LANGRIDGE, P.J., SMITH, K., VAN NIEKERK, M.S., WINTERS, Z.E. \& WRIGHT, N.C. 1995. Anorexia nervosaa prevalence study. South African Medical Journal, 59:992-993.

ELLISON, C.G., GAY, D.A. \& GLASS, T.A. 1989. Does religious commitment contribute to individual life satisfaction? Social Forces, 68:100-123.

FERRARO, K.F. \& ALBRECT-JENSEN, C.M. 1991. Does religion influence health? Journal for the Scientific Study of Religion, 30:193-202.

GARNER, D.M. \& GARFINKEL, B.E. 1985. Handbook of psychotherapy for anorexia nervosa and bulimia. New York: Guilford.

GOTTESFELD, J. 1979. Abnormal psychology: A community mental health perspective. Chicago: SAA.

GOVERNMENT OF BRITISH COLUMBIA. 2003. Special education. Ontaria: Ministry of Education.

HALSTEAD, J.M. \& TAYLOR, M.J. 1996. Values in education and education in values. London: Falmer.

HARTMANN, L. 2003. Body fascism: Another form of discrimination. London: Royal College of Psychiatrists.

IDLER, E.L. 1987. Religious involvement and the life of the adolescent: Some hypotheses and an initial test. Social Forces, 66:226-238.

KAUFMAN, M.R. \& HEIMAN, H. 1965. Evolution of psychosomatic concepts: Anorexia nervosa: A paradigm. London: Hograth. 
KOVAKS, M., BECK, A.T. \& EISSMAN, A. 1975. Hopelessness: An indicator of suicidal risk. Suicide, 5:98-103.

LEVINE, M.P. 1983. Developing a pilot community program for the prevention of eating disorders. Ohio: Columbus.

LEVINE, M.P. 2003. The psychology of eating disorders: A lesson plan for Grades 7-12. Ohio: Columbus.

MACLAUGHLIN, T.H. 2004. Values in education. London/New York: Continuum.

MARCHUK, J. 1997. Eating disorders: A continuum. Alberta: Alberta Educators' Association.

MINISTRY OF EDUCATION. 2003. Resources for educators - eating disorders. British Columbia: Government Printer.

NATIONAL DEPARTMENT OF EDUCATION. 2001. Draft revised national curriculum statement. Pretoria: National Department of Education.

NICOLLS, D. \& BRYANT-WAUGH, R. 2003. Children and young adolescents. (In Treasure, J.S., Schmidt, U., Van Furth, E., ed. Handbook for eating disorders. West Sussex: Wiley. p. 67-68.)

NORRIS, D.L. 1996. Eating disorders: The adolescent epidemic. Journal of Medical Involvement, 4(9):39-45.

OATES, W.E. 1970. When religion gets sick. Philadelphia: Westminister.

OLIVIER, L., HAASBROEK, C.P., BEUERS, D., DE JONGH VAN ARKEL, J.T., MARCHETTI, M.C., ROOS, J.L., SCHURING, E.M., SCHURINK, W.J. \& VISSER, M.J. 1991. The phenomenon of family murder in South Africa: An exploratory study. Pretoria: Human Sciences Research Council.

O'NEILL, S. 1982. Starving for attention. New York: Continuum.

PEARSON, R.E. 1982. Support: Exploring of a basic dimension of informal help and counselling. The Personnel and Guidance Journal, 61:83-87.

PETERS, C. 1994. Anorexia nervosa and bulimia: Focus on schools. National Adolescent Anorexia Society, 7(4):1-2.

PETERSEN, L.R. \& ROY, A. 1985. Religiosity, anxiety, and meaning and purpose: Religion's consequences for psychological well-being. Review of Religious Research, 27:49-62.

PRATT, J.M. 1983. Junior high and high school: Anorexia nervosa and bulimia. New York: Harper \& Row.

REPUBLIC OF SOUTH AFRICA. 1996. Constitution of the Republic of South Africa, 108 of 1996. Pretoria: Government Printer.

SARIE. 6 Maart 2002. nr. 5. Kaapstad: Nasionale Pers.

SCHUTTE, C.J. 2004. Anorexia nervosa: 'n Psigodinamiese ondersoek. Potchefstroom: s.n.

SHILHAVY, B. 2002. A biblical view of health. http://www.shilhavy.com/ americanfamily/biblicalhealth.htm [13 Feb. 2004].

SODERQUIST, A. 2002. Health lesson plans. Grades 9-12. http://school.discover.com.lessonplans/programs/eatingdisorders [14 Feb. 2004].

SOURS, J. 1980. Starving to death in a sea of objects. New York: Jason Aronson.

STOKER, H.G. 1941. Die grond van die sedelike. Stellenbosch: Pro Ecclesia.

TOOTELL, C. 2000. Survival suggestions for schools. National Adolescent Anorexia Society, 7(3):14-17.

VAN DER WALT, B.J. 1999. What to do when you are ill? Potchefstroom: Institute for Reformational Studies. 
VOGEL, H.M. 2004. Case studies of adolescents with eating disorders. Pretoria: s.n.

VRIEZEN, Th. C. 1966. Hoofdlijnen der teologie van het Oude Testament. Wageningen: Veenman.

WALFISH, S. \& WEINBERG, R.B. 1979. Social support systems for crisis intervention. Crisis Intervention, 10:122-142.

WALKER, P. 2003. No shame no blame. Washington: National Center for Overcoming Overeating.

WALLER, G. \& SHAW, J. 1994. The media influence on eating problems. London: Athlone.

WHO. 1993. Health promotion. A discussion Document on the Concept and Principles. Copenhagen: WHO Regional Office Europe.

WOOLEY, S.C. \& WOOLEY, O.W. 1985. Handbook of psychotherapy for anorexia nervosa and bulimia. New York: Guilford.

WORLD HEALTH ORGANISATION see WHO

YATES, S.A. 2000. Eating disorders: What you need to know about this prevalent problem. Today's Christian Woman, (22)1:18.

\section{Key concepts:}

adolescents

Bible and self-image

eating disorders

school: eating disorders; handling of

\section{Kernbegrippe:}

adolessente

Bybel en selfbeeld

eetversteurings

skool: eetversteurings; hantering van 
